\title{
Universiteit
}

Leiden

The Netherlands

\section{Revenue Effects of Tax Facilities for Pension Savings}

Caminada, C.L.J.; Goudswaard, K.P.

\section{Citation}

Caminada, C. L. J., \& Goudswaard, K. P. (2008). Revenue Effects of Tax Facilities for Pension Savings. Atlantic Economic Journal, 36(2), 233-246. Retrieved from https://hdl.handle.net/1887/15457

Version: $\quad$ Not Applicable (or Unknown)

License: $\quad$ Leiden University Non-exclusive license

Downloaded from: https://hdl.handle.net/1887/15457

Note: To cite this publication please use the final published version (if applicable). 
Source: K. Caminada and K. Goudswaard (2008), 'Revenue Effects of Tax Facilities for Pension Savings', Atlantic Economic Journal 36 (2), pp. 233-246.

\title{
Revenue Effects of Tax Facilities for Pension Savings *
}

\section{Koen Caminada}

c.l.j.caminada@law.leidenuniv.nl

Economics Department, Leiden University P.O. Box 9520, 2300 RA, The Netherlands phone: ++3171527 7756

\section{Kees Goudswaard}

k.p.goudswaard@law.leidenuniv.nl

Economics Department, Leiden University P.O. Box 9520, 2300 RA, The Netherlands phone: ++3171527 7756

\begin{abstract}
Many countries have tax facilities for pension savings. These facilities are often associated with the application of the cash-flow treatment of pensions: pension contributions are tax-exempt, capital income of pension funds is tax-exempt, and pension benefits are taxed, but usually at a relatively low rate. This paper investigates the revenue effects of a cash-flow tax regime for pension savings by full present-value calculations. A comprehensive income tax system is used as a benchmark.

We present an empirical analysis for the Netherlands as a typical example of a country with funded pensions. Our calculations show that current taxation of pensions implies a major tax revenue loss. For the year 2003 we estimate a 'fiscal subsidy' of 1.4 to 1.5 percent of GDP.
\end{abstract}

JEL-classification: E62, H24, and H55

Keywords: pension saving, tax treatment, tax revenue loss

\footnotetext{
"Revised version of a paper presented at the $60^{\text {th }}$ Congress of the International Institute of Public Finance, Milan, Italy (August $23^{\text {rd }}-26^{\text {th }}, 2004$ ), and at the 60th International Atlantic Economic Conference New York, United States of America (October $7^{\text {th }}, 2005$ ). We thank Jenny Ligthart, Henk Vording, Guido Suurmond, Gerbert Romijn, and the participants of our sessions of the IIPF Congress and the IAE Conference, and the referee of this journal for valuable comments on earlier drafts of this paper. The usual disclaimer applies.
} 


\section{I ntroduction}

In many countries pensions are the subject of great interest. Various studies have reviewed the ability of the pension systems to survive in view of the increasing aging of the population (Wise, 2005; Van Ewijk et al., 2006; Gruber \& Wise, 1999). ${ }^{1}$ In this context, the financing of pensions is important. Funded (private) pension systems are generally found to be less vulnerable to demographic shocks than public pay-as-you-go systems. This is the reason underlying recent pension reforms in for example Sweden and Germany (Sinn, 2005). These countries try to partially switch to funded pensions. A number of other countries already have substantial funded pension programs, such as the Unites States, Japan, the United Kingdom, Denmark, and the Netherlands. In many countries pension funding is stimulated through a favorable tax treatment of pension savings. A wide variety of tax regimes for occupational private pension saving are in place around the world. Generally, pension saving is taxed at a relatively low rate, although the revenue loss due to tax facilities for pension savings and/or pension tax expenditures may differ across countries. A strong fiscal stimulus to build up pension capital will support funding. However, these tax facilities may become an expensive business for governments. This paper investigates the ex ante revenue effects of a cash-flow tax regime for pension savings by full present-value calculations. To that end, we use a specified form of a comprehensive income tax system as benchmark. We employ an empirical analysis for the Netherlands, as a typical example of a country with an extensive funded pension system.

The paper is organized as follows. The next section presents an overview of the tax treatment of pensions in OECD countries. We then model the ex ante revenue implications of the various tax treatments of pension savings. We choose for a partial equilibrium approach, so behavioral effects of implementing the benchmark tax rule will not be taken into account in our analysis. ${ }^{2}$ For the empirical analysis we use Income Panel Data from Statistics Netherlands (2006) for the years 1990-2003. We simulate the revenue effect associated with the Dutch tax rule on pension saving for the period 1990-2003, which includes a major tax reform. In the final section some conclusions are presented.

\section{Tax treatment of private pensions in OECD countries}

The fiscal stimulus of pension saving in several countries is associated with the application of the cash-flow treatment of pensions under the personal income tax: pension contributions are taxexempt, capital income of pension funds is tax-exempt, and pension benefits are taxed. This form can be described as EET, with E denoting an exemption or relief from tax and T denoting a point at which tax is payable. The tax treatment of pension saving can have other forms as well. Contributions can be exempted, while the withdrawals and the accrual return on accumulated funds are taxed (ETT). Under a comprehensive income tax system (TTE) all income is taxed when it is received, so saving is from taxed income, interest income from savings is taxed, but proceeds of savings do not suffer further tax.

Yoo \& de Serres (2004) have presented an overview of the practice of taxation of private pension plans in OECD countries; see Table 1.

1 See for a detailed description of pension systems in Europe the report of the European Commission (2006).

2 An intertemporal computable general equilibrium model with overlapping generations could be used to take into account behavioral responses to changes in tax regimes. For example, a less favorable tax treatment of pension savings may affect its size and therefore future tax revenues. It may also affect labor supply. 
Table 1 Tax treatment of private pensions in $2003^{a}$

\begin{tabular}{|c|c|c|c|}
\hline & Contributions $^{b}$ & Fund & Pension payments $^{c}$ \\
\hline Australia ${ }^{d}$ & $\mathrm{~T}$ & pT & $\mathrm{T} / \mathrm{PE}$ \\
\hline Austria $^{\mathrm{d}}$ & $\mathrm{T}(\mathrm{PE})$ & $E$ & $\mathrm{~T} / \mathrm{PE}$ \\
\hline Belgium $^{d}$ & $\mathrm{E}(\mathrm{TC})$ & $\bar{E}$ & $\mathrm{~T} / \mathrm{PE}$ \\
\hline Canada & $\mathrm{E}$ & $\mathrm{E}$ & $\mathrm{T}$ \\
\hline Czech Republic $^{d}$ & $(T(S)$ & $\mathrm{E}$ & $\mathrm{T} / \mathrm{PE}$ \\
\hline Denmark & $\mathrm{E}$ & pT $(15 \%)$ & $\mathrm{T}$ \\
\hline Finland & $\mathrm{E}$ & $\mathrm{E}$ & $\mathrm{T}$ \\
\hline France & $\mathrm{E}$ & $E$ & $\mathrm{~T} / \mathrm{PE}$ \\
\hline Germany & $\mathrm{E}$ & $\mathrm{E}$ & $\mathrm{T} / \mathrm{PE}$ \\
\hline Greece & $\mathrm{E}$ & $\mathrm{E}$ & $\mathrm{T}$ \\
\hline Hungary d, e & $\mathrm{T}$ & $\mathrm{E}$ & $\mathrm{E}$ \\
\hline Iceland & $\mathrm{E}$ & $\bar{E}$ & $\bar{T}$ \\
\hline Ireland & $\mathrm{E}$ & $\bar{E}$ & $\mathrm{~T} / \mathrm{PE}$ \\
\hline Italy & $\mathrm{E}$ & pT (12.5\%) & $\mathrm{T} / \mathrm{PE}$ \\
\hline Japan & $\mathrm{E}$ & E & $\mathrm{T} / \mathrm{PE}$ \\
\hline Korea & $\mathrm{E}$ & $\mathrm{E}$ & $\mathrm{T} / \mathrm{PE}$ \\
\hline Luxembourg $^{d}$ & $\mathrm{E}$ & $\mathrm{E}$ & $T$ \\
\hline Mexico & $E$ & $E$ & $\mathrm{~T} / \mathrm{PE}$ \\
\hline Netherlands & $\mathrm{E}$ & $\mathrm{E}$ & $\mathrm{T}$ \\
\hline New Zealand d & $\mathrm{T}$ & $\mathrm{T}$ & $\mathrm{E}$ \\
\hline Norway & $E$ & E & $\mathrm{T}$ \\
\hline Poland & E & $E$ & $\mathrm{~T}$ \\
\hline Portugal ${ }^{d}$ & $\mathrm{E}(\mathrm{TC})$ & $E$ & $\mathrm{~T} / \mathrm{PE}$ \\
\hline Slovak Republic & $\mathrm{E}$ & $\mathrm{E}$ & $\mathrm{T}(15 \%)$ \\
\hline Spain & $\mathrm{E}$ & $\mathrm{E}$ & $\mathrm{T}$ \\
\hline Sweden & $\mathrm{E}$ & pT $(15 \%)$ & $\mathrm{T}$ \\
\hline Switzerland & $\mathrm{E}$ & $\mathrm{E}$ & $\mathrm{T}$ \\
\hline Turkey & $\mathrm{E}$ & $E$ & $E$ \\
\hline United Kingdom & $E$ & $E$ & $\mathrm{~T}$ \\
\hline United States & $\mathrm{E}$ & $\mathrm{E}$ & $\mathrm{T}$ \\
\hline
\end{tabular}

Note: $\mathrm{E}=$ exempt; $\mathrm{T}=$ taxed under personal income tax; $\mathrm{TC}=$ tax credit; $\mathrm{PE}=$ partial exemption or deduction from taxation; $\mathrm{S}=$ state subsidy; $\mathrm{pT}=$ partial taxation.

a. Private pension refers to mandatory or voluntary funded privately managed pension schemes.

b. Tax-deductible contributions are subject to a certain limit in most countries.

c. This generally concerns the tax treatment in the case of annuities. Many countries allow pension benefits to be withdrawn in the form of lump sums, in which case a partial exemption is granted so as to preserve tax neutrality with annuities.

d. The tax treatment of the employer's contribution is different from that of the employee's.

e. Mandatory contributions are fully taxed, but voluntary contributions receive tax credits.

Sources: Antolín et al. (2004, p. 29) and Yoo \& de Serres (2004, p. 80)

Twelve OECD countries (Canada, Finland, Greece, Iceland, Luxembourg, the Netherlands, Norway, Poland, Spain, Switzerland, United Kingdom and the United States) apply the EET- regime in which withdrawals are subject to the progressive income tax rates, although often at preferential rates. Another ten countries (Austria, Belgium, France, Germany, Ireland, Japan, Korea, Mexico, Portugal and the Slovak Republic) also apply an EET-regime, but in these countries withdrawals are taxed more leniently than in the first group (for example through partial tax free withdrawal) or contributions are granted a tax credit rather than a full deduction. In Italy, Denmark and Sweden, taxation on contributions is also deferred, but accrued income from fund investment is taxed, albeit at preferential rates (ETT). In Australia, Austria, Czech Republic and New Zealand contributions are taxed. New Zealand comes close to a pure comprehensive income tax regime (TTE), while Australia is characterized as a TTT regime, but contributions can be partially exempted and investments earnings and benefits are taxed at a preferential rate. 


\section{Revenue effects under different tax regimes}

In this section we try to give an indication of the ex ante revenue implications of different tax treatments of pension savings. ${ }^{3}$ It should be noted that theoretical literature does not point at an appropriate tax system for pension savings. We use a specified form of a comprehensive income tax system (see below) as a benchmark (cf. Booth \& Cooper, 2002). ${ }^{4}$ The tax due will be defined when applying the benchmark rule and when using an alternative tax rule EET. The structural revenue effect can be calculated in terms of net present value for application of the EET-rule and of the benchmark rule. The difference between the tax yield when using the benchmark rule and when using the EET-rule is called the 'fiscal subsidy' associated with the EET-rule. The expenditure side of the pension scheme must also be incorporated into the analysis. In the model described below we define for the different tax regimes both the present value of future tax receipts and the present value of pension capital, which will be converted into expenditure streams.

Next to this present-value approach, a cash-flow approach could be used. In the latter approach, revenue effects are measured as the net amount of revenues foregone on contributions and accrued investment income and the revenues collected on withdrawals in the same year (corresponding to contributions made in previous years). As Yoo \& de Serres (2004, p. 81) argue, the present-value approach has the advantage that it is not influenced by the history of past contributions or by demographic changes. Because this method takes into account the intertemporal shift in tax revenues, it provides a more accurate picture of the budgetary costs of tax-favored pension schemes.

It should be mentioned that our model focuses on revenue effects and does not include other economic effects or social efficiency considerations. One of the purposes of favorable tax treatment of pension plans in many countries is to avoid moral hazard of workers, who may otherwise be tempted to consume too much of their earnings during work life and free ride on the social safety net once they retire (OECD, 2001, p. 30). ${ }^{5}$ These advantages need to be weighed carefully against the fiscal revenue effects of different tax treatments of pension saving, but also against the risk of poor targeting, as the tax relief may benefit groups who are not affected by moral hazard and whose prospective pension income is well above the social safety net. This paper will not attempt to quantify such welfare effects.

The model

Tax rule TTE (benchmark)

We compare the revenue of a cash flow tax treatment of pension savings with a specific comprehensive income tax, in which no relief is given for the investment, and the proceeds of the investment are taxed, but pension benefits are exempt from tax. Pension benefits are based on the pension capital $\mathrm{V}_{\mathrm{t}}$ which is accumulated from time $\mathrm{t}=0$ to $\mathrm{t}=\mathrm{N}$. In the benchmark case the pension saving investment before tax, $C_{0}$, proceeds at rate $r$. During the accumulation period the annual return on the investment is taxed at rate $\mathrm{T}_{\mathrm{g}}$. The accruing process of the value of the pension capital $\mathrm{V}_{\mathrm{t}}$ (after tax) can be written as:

$V_{0}=C_{0}$

$V_{1}=C_{0} \cdot(1+r)-r \cdot \tau_{g} \cdot C_{0}=C_{0} \cdot\left(1+r \cdot\left(1-\tau_{g}\right)\right)$

$V_{2}=V_{1} \cdot\left(1+r \cdot\left(1-\tau_{g}\right)\right)$

$V_{t}=C_{0} \cdot\left(1+r \cdot\left(1-\tau_{g}\right)\right)^{t}$

3 The analysis is limited to income tax; corporation tax has not been taken into account.

4 The United Kingdom's Inland Revenue states TTE as an appropriate benchmark for the calculation of tax expenditures; see Booth \& Cooper (2002, p. 84).

5 See Butare (1998) on the roles of government and markets in the case of pensions, and on market failure to justify (tax) subsidies. 
So, the net present value of pension accumulated under the benchmark tax rule amounts

$V_{\text {TTE }, 0}=C_{0} \cdot \frac{\left(1+r \cdot\left(1-\tau_{g}\right)\right)^{N}}{(1+\delta)^{N}}$,

where the discount rate is denoted by $\delta$.

In the benchmark case no tax relief is given for the pension investment $\mathrm{C}_{0}$ at time $t=0$; the pension saving investment $C_{o}$ is out of disposable income (i.e. after tax $T_{c}$ ). We denote the tax revenue under the benchmark rule in net present values at $\mathrm{t}=0$ as

$T_{T T E, 0}=\tau_{c} \cdot C_{0}+\tau_{g} \cdot r \cdot\left[\sum_{t=1}^{N} \frac{C_{o} \cdot\left(1+r \cdot\left(1-\tau_{g}\right)\right)^{t}}{(1+\delta)^{t}}\right]$

It should be noted that we assume a fixed level of (net) pension saving investment irrespective of whether the TTE-rule or EET-rule would be applied. In other words, we calculate the net tax costs per unit of contribution. Behavioral effects of implementing another tax rule will not be taken into account. As a result, our model generates different levels of net pension capital and net pension benefits when the TTE-rule and the EET-rule will be applied. ${ }^{6}$ Alternatively, one could argue that a model with a fixed amount of net pension capital and net pension benefits is more appropriate. However, in such a model it is overlooked that an EET-tax code stimulates the build-up of pension capital, and is therefore likely to yield a higher level of pension benefits.

Tax rule EET

The favorable tax treatment of pension savings in several countries is associated with the application of the cash-flow treatment of pensions under the personal income tax. In this case no annual return tax is levied during the accumulation period $\left(T_{g}=0\right)$, so the pension capital accrues by rate $r$ each period: $V_{t}=(1+r) \cdot V_{t-1}$. Pension capital will generate the amount available for benefits at $\mathrm{t}=\mathrm{N}$. The net present value of pension capital build-up under the cash-flow treatment of pensions under the personal income tax can be written as:

$V_{E E T, 0}=C_{0} \cdot \frac{(1+r)^{N}}{(1+\delta)^{N}}$

We denote the tax revenue of the cash flow treatment of pensions under the personal income tax in net present values at $\mathrm{t}=0$ as

$T_{E E T, 0}=\tau_{b} \cdot C_{0} \cdot \frac{(1+r)^{N}}{(1+\delta)^{N}}$

where $T_{b}$ is the tax rate on pension benefits.

Fiscal subsidy on pension savings

The pension capital build-up consists of two components: the pension contribution payments and the capital growth. When the benchmark rule applies, each of these two components would be taxed at the time of the build-up. When the EET-rule is applied, the levy only takes place on the pension benefit payments. So, the fiscal subsidy on pension savings in net present values can be denoted as

$S=T_{T T E, 0}-T_{E E T, 0}=\tau_{c} \cdot C_{0}+\tau_{g} \cdot r \cdot\left[\sum_{t=1}^{N} \frac{C_{0} \cdot\left(1+r \cdot\left(1-\tau_{g}\right)\right)^{t}}{(1+\delta)^{t}}\right]-\tau_{b} \cdot C_{0} \cdot \frac{(1+r)^{N}}{(1+\delta)^{N}}$

6 Moreover, the estimation of the revenue effect is restricted to direct taxation. It does not take into account that indirect taxes partially can offset the effects of the system of direct taxation. Paying less direct taxes increases spending over the life cycle and therefore leads to higher revenues from indirect taxes. 
This means that there can be several aspects to the tax advantage of using the EET-rule compared to the benchmark rule:

(a) the difference between the marginal tax rates on contributions and withdrawals due to rate progression, and because pensioners may be taxed at preferential rates $\left(\mathrm{T}_{\mathrm{C}}\right.$ and/or $\mathrm{T}_{\mathrm{g}}$ versus $\left.\mathrm{T}_{\mathrm{b}}\right)$;

(b) the effect of not collecting any annual return tax on pension capital during the build-up period, in combination with the later moment in time of the tax payment.

These partial effects of the fiscal advantage of using tax rule EET can be disentangled as follows. In principle, there is no gain from deferral if $\delta=r$ and the capital tax $T_{g}$ is zero. We therefore distinguish the effects of the positive capital tax on the one hand (holding $\mathrm{T}_{\mathrm{c}}$ and $\mathrm{T}_{\mathrm{b}}$ equal) and the differential treatment of young and old people, if any, on the other hand (holding $\mathrm{T}_{\mathrm{g}}$ at zero).

The partial effect of low senior tax rates, S(a), can be calculated as:

$$
S(a)=\tau_{c} \cdot C_{0}-\tau_{b} \cdot C_{0} \cdot \frac{(1+r)^{N}}{(1+\delta)^{N}}
$$

The partial effect of deferral tax payment, $S(b)$, is the combined effect of not collecting any annual return tax on pension capital, and the later moment in time of the tax payment. This partial effect, $\mathrm{S}(\mathrm{b})$, ignores rate progression, i.e. we calculate the fiscal subsidy for $\mathrm{T}_{\mathrm{g}}>0$.

$$
S(b)=\tau_{g} \cdot r \cdot\left[\sum_{t=1}^{N} \frac{C_{0} \cdot\left(1+r \cdot\left(1-\tau_{g}\right)\right)^{t}}{(1+\delta)^{t}}\right]
$$

The no-fiscal subsidy case

A fiscal subsidy of the EET-scheme, if any, leads to a lower effective tax burden compared to a comprehensive income tax system (cf. OECD, 1994). Governments may conclude that fiscal support of pension savings has become an expensive business. Obviously, also under the EET-rule it is possible to raise tax rates to reduce the fiscal subsidy on pension savings.

We calculate the level of the tax rate under the EET-rule that would generate exactly the same amount of tax revenue compared to the benchmark rule. We denote this equivalent tax revenue yielding rate on pension benefits as $\mathrm{T}_{\mathrm{b}} *$. The fiscal subsidy would disappear for:

$$
S=0 \Rightarrow T_{T T E, 0}-T_{E E T, 0}=0 \Rightarrow \tau_{b}^{*}=\left[\tau_{c}+\tau_{g} \cdot r \cdot \sum_{t=1}^{N} \frac{\left(1+r \cdot\left(1-\tau_{g}\right)\right)^{t}}{(1+\delta)^{t}}\right] \cdot\left[\frac{(1+\delta)^{N}}{(1+r)^{N}}\right]
$$

The level of the equivalent pension benefit tax rate depends on the level of the tax rates of the benchmark case, on the level of the annual investment return rate $r$, and on the pension capital build-up period N. ${ }^{7}$ Note that the equivalent pension benefit tax rate will generally be (significantly) higher than the tax rates in the benchmark case.

\section{A numerical application for the Netherlands}

Dutch pensions

From the OECD countries, the Netherlands has the highest relative amount of assets in tax-favored retirement saving plans: total assets represent more than 110 percent of GDP (Antolín et al., 2004, p. 30). In addition, participation in (mandatory) private pension plans and the share of these plans in total retirement income are high. More than 90 percent of the employees have, on attaining the 
age of 65 , supplementary pension insurance in addition to the basic flat rate public pension for all residents (OAP). Therefore, it can be expected that the tax treatment of these supplementary pensions has a relatively high significance in terms of net fiscal revenues. We analyze the case of the Netherlands as a typical example of an EET-regime (Bovenberg, 2003). However, it is not a pure EET-regime, because withdrawals are taxed at a lower rate, because pension benefit recipients over 65 years of age do not pay any contributions to the basic public old age pension scheme. In addition, marginal income tax rates on withdrawals are often lower than marginal rates on contributions because of rate progression.

Assumptions

We will simulate the revenue effects of the Dutch tax treatment of pension savings. The basis of the simulation is the amount of Dutch pension contributions which were deducted in the year 2000 (14.9 billion euros, or 3.7 percent of GDP). A number of assumptions have to be made.

The pension contributions entered into in 2000 mature for an unknown number of years until they pay out as benefits. We estimated a weighted average duration of capital build-up of around 15 years. ${ }^{8}$ The simulations have also been carried out with durations of 10 and 20 years.

We use a discount rate of 3 percent, close to the real interest rate on Dutch government debt. This discount rate is also used in pension studies by the European Union (Economic Policy Committee, 2006). In a second simulation we use a higher discount rate of 5 percent. Also, we have set the rate of return on pension capital equal to the discount rate. This methodology avoids that risk premiums are treated in an asymmetric manner and is in line with current international conventions (cf. Van Ewijk et al., 2006).

We assume for the sake of simplicity that the accumulated capital will be paid out from the age of 65 . The average age of death is 77 , so the average number of years during which the pension capital is paid out as benefits is assumed to be 12 .

In order to estimate the relevant tax rates, we used Income Panel Data from Statistics Netherlands (2006) which contain extensive information on the distribution of taxable income across income groups. This makes it possible to classify taxpayers by tax brackets. Pensioners of 65 years and older have 70 percent of their income in the first or second tax bracket, 20 percent in the third tax bracket and the remainder in the highest tax bracket. This gives a weighted seniors tax rate $\left(T_{b}\right)$ of about 25.5 percent on supplementary pension. Next, we estimated the tax rate to be applied to the pension contributions $\left(T_{c}\right)$, which are tax-deducted under the EET-rule and paid out of after tax income in the benchmark case. We find a weighted effective tax rate for the year 2000 of 44 percent. ${ }^{9}$ During the accumulation period the annual return will be taxed at the same rate under the benchmark rule, so $\mathrm{T}_{\mathrm{c}}=\mathrm{T}_{\mathrm{g}}=44$ percent.

Results

We calculate the present value of taxes paid and of pension capital (pension expenditure) under the Dutch tax rule and under the benchmark rule. No account is taken of the possible behavioral effects of implementing the benchmark rule. The difference between the tax yield when using the benchmark rule and when using the Dutch tax rule is called the 'fiscal subsidy' associated with the Dutch tax rule. Table 2 shows the results of a number of simulations, including a sensitivity analysis.

7 Note that for $r=\delta \Rightarrow \tau_{b}^{*}=\tau_{c}+\tau_{g} \cdot r \cdot \sum_{t=1}^{N} \frac{\left(1+r \cdot\left(1-\tau_{g}\right)\right)^{t}}{(1+\delta)^{t}}$

8 This estimation is confirmed by CPB Netherlands Bureau of Economic Policy Analysis (not published). The relative low duration (below half of the maximum time period people could build up their pension) can partly be explained by the high relative weight of pension contributions of older workers with on average high incomes.

9 Account has been taken in these calculations of the so-called threshold effect: tax payers may go into a lower tax bracket because of the use of the tax deduction. On this see Caminada \& Goudswaard (1996). 
Table 2 Effects of different tax treatments of pension saving $x$ billion euros in NPV

\begin{tabular}{|c|c|c|c|c|c|c|}
\hline & \multicolumn{3}{|c|}{$\begin{array}{l}\text { Rate of return } 5 \% \\
\text { (discount rate } 5 \% \text { ) }\end{array}$} & \multicolumn{3}{|c|}{$\begin{array}{l}\text { Rate of return } 3 \% \\
\text { (discount rate } 3 \% \text { ) }\end{array}$} \\
\hline & $\begin{array}{l}\text { benchmark } \\
\text { tax rule } \\
\text { TTE (1) }\end{array}$ & $\begin{array}{l}\text { Dutch } \\
\text { tax rule } \\
\text { EET (2) }\end{array}$ & $\begin{array}{l}\text { difference } \\
(1)-(2) \\
\end{array}$ & $\begin{array}{l}\text { benchmark } \\
\text { tax rule } \\
\text { TTE }(1) \\
\end{array}$ & $\begin{array}{l}\text { Dutch } \\
\text { tax rule } \\
\text { EET (2) }\end{array}$ & $\begin{array}{r}\text { difference } \\
(1)-(2) \\
\end{array}$ \\
\hline \multicolumn{7}{|l|}{$\begin{array}{l}\text { Period of pension capital growth: } \\
20 \text { years }\end{array}$} \\
\hline $\begin{array}{l}\text { Tax revenue } \\
\text { Fiscal subsidy current tax rule } \\
\text { (-) partial effect low senior tax rate } \\
\text { (-) partial effect deferral tax payment }\end{array}$ & 11.7 & 3.8 & $\begin{array}{l}+7.9 \\
+2.8 \\
+5.1\end{array}$ & 10.0 & 3.8 & $\begin{array}{l}+6.2 \\
+2.8 \\
+3.4\end{array}$ \\
\hline $\begin{array}{l}\text { Accumulated capital (pension } \\
\text { expenditure) }\end{array}$ & 9.8 & 14.9 & -5.1 & 11.5 & 14.9 & -3.4 \\
\hline \multicolumn{7}{|l|}{$\begin{array}{l}\text { Period of pension capital growth: } \\
15 \text { years }\end{array}$} \\
\hline $\begin{array}{l}\text { Tax revenue } \\
\text { Fiscal subsidy current tax rule } \\
\text { (-) partial effect low senior tax rate } \\
\text { (-) partial effect deferral tax payment }\end{array}$ & 10.6 & 3.8 & $\begin{array}{l}+6.8 \\
+2.8 \\
+4.0\end{array}$ & 9.2 & 3.8 & $\begin{array}{l}+5.4 \\
+2.8 \\
+2.6\end{array}$ \\
\hline $\begin{array}{l}\text { Accumulated capital (pension } \\
\text { expenditure) }\end{array}$ & 10.8 & 14.9 & -4.1 & 12.3 & 14.9 & -2.6 \\
\hline \multicolumn{7}{|l|}{$\begin{array}{l}\text { Period of pension capital growth: } \\
10 \text { years }\end{array}$} \\
\hline $\begin{array}{l}\text { Tax revenue } \\
\text { Fiscal subsidy current tax rule } \\
\text { (-) partial effect low senior tax rate } \\
\text { (-) partial effect deferral tax payment }\end{array}$ & 9.4 & 3.8 & $\begin{array}{l}+5.6 \\
+2.8 \\
+2.8\end{array}$ & 8.4 & 3.8 & $\begin{array}{l}+4.6 \\
+2.8 \\
+1.8\end{array}$ \\
\hline $\begin{array}{l}\text { Accumulated capital (pension } \\
\text { expenditure) }\end{array}$ & 12.1 & 14.9 & -2.8 & 13.1 & 14.9 & -1.8 \\
\hline
\end{tabular}

Explanatory note:

$C_{0}=14.9$ billion euro; $T_{c}=44.0$ percent, $T_{g}=44.0$ percent; $T_{b}=25.5$ percent; $n=10,15$, or 20 years; $r=3$ or 5 percent, and $\delta=3$ respectively 5 percent. All amounts are $x$ billion euros. Euros in net present value (NPV) so that the amounts relating to the various different years have been made comparable; a discount rate of 3 percent has been used.

Source: own calculations; all data and simulation results are available upon request.

Investment return and discount rate

At an annual rate of return on the pension capital of 3 percent and a discount rate of 3 percent the tax actually paid - in terms of net present value and measured over a period of 15 years - is 3.8 billion euros, compared to 9.2 euros in the benchmark case. The actual tax paid therefore amounts to only 41 percent of what would be owed if the benchmark rule were to be applied. In other words, application of the Dutch tax rule for pensions gives a fiscal subsidy of 5.4 billion euros. At a higher rate of return on investment ( 5 percent) the fiscal subsidy increases to 6.8 billion euros.

We performed our simulations with several other discount rates. It appears that the result is not very sensitive to the discount rate used. The fiscal subsidy reported in Table 2 increases by 0.5 to 0.9 billion euros per point higher discount rate, depending on the length of the build-up period. 
Duration

We also simulated durations of capital build-up of 10 and 20 years. Measured over a ten year period, the Dutch tax rule 'only' gives a subsidy of 4.6 billion euros (in terms of net present value, at a rate of return of 3 percent). A doubling of the duration from 10 to 20 years generates a substantially higher subsidy of 6.2 billion euros due to the additional capital growth. This capital growth remains untaxed during the build-up period of the pension capital under the EET-regime. In addition, the higher annual pension benefit payments arising from this will only be taxed at a relatively low seniors rate. In other words, the fiscal subsidy on pension savings increases when pension schemes have a longer duration before they start to pay out pension benefits.

Partial effects

The relatively low tax rate for seniors and the deferral of tax payment together generate the fiscal advantage associated with the Dutch tax rule. In the case of a 5 percent rate of return and a period of pension capital growth of 10 years, the partial effect of the deferral of tax payment is about equal to the effect of the lower senior rate. The share of the deferral of tax payment in the total fiscal subsidy increases when pension schemes have a longer duration before they start to pay out pension benefits.

Pension capital

The simulations show that the present value of accumulated pension capital (and thus of pension expenditure) is higher under the Dutch tax code than under the benchmark tax code. ${ }^{10}$ The difference is larger at a longer build-up period and a higher investment return. This result, of course, depends on our assumption of constant contributions in the two regimes. Nevertheless, it can be concluded that the Dutch tax code favors the build-up of pension capital, and therefore the level of pension benefits.

\section{Time-series analysis}

Fiscal subsidy $1990-2000$

The calculations for the year 2000 show that the Dutch tax rule implies a revenue loss to the Treasury compared to the benchmark. Structurally, the fiscal subsidy on pension savings at a rate of return on the pension capital of 3 percent and a duration of 15 years comes to about 5.4 billion euros (1.34 percent GDP) in net present value terms. ${ }^{11}$

Figure 1 shows the estimates for all the years in the period 1990-2000 calculated in the same way as explained above for the year 2000. ${ }^{12}$ The fiscal subsidy rises during this period by 38 percent due to higher pension contributions. In the case of a 3 percent yield, the fiscal subsidy rises from 0.97 to 1.34 percent of GDP; if a yield of 5 percent is used, the fiscal subsidy rises from 1.22 percent in 1990 to 1.69 percent of GDP in 2000.

Estimates fiscal subsidy for $2001-2003$

The analysis so far refers to the situation for the year 2000. Under the new Income Tax Act 2001 accumulation of capital - if the benchmark rule would be applied - should be taxed at a lower rate

10 Note that the amount of pension capital as build-up in $\mathrm{N}$ years will always be less under the benchmark tax rule where a tax rate is levied on the proceeds of the investments $\left(T_{g}>0\right)$.

$V_{T T E, 0}-V_{E E T, 0}=C_{0} \cdot\left[\frac{\left(1+r \cdot\left(1-\tau_{g}\right)\right)^{N}-(1+r)^{N}}{(1+\delta)^{N}}\right] \quad$ so $\quad V_{T T E, 0}<V_{E E T, 0} \quad$ for $\quad \tau_{g}>0$

11 Yoo \& de Serres (2004) also estimated the net tax cost of pension savings in the Netherlands, using the present-value approach. They find that overall cost arising from contributions made in 2000, are almost 1.2 percent of GDP (p. 94), which result is very similar to ours.

12 The amount of fiscal subsidy we find for recent years is lower than in previous work (Caminada and Goudswaard, 2004) due to several more realistic assumptions made and due to improved data. 
than was the case in the year 2000. Also, the other relevant tax rates have been reduced. A special feature in the new legislation is a 30 percent tax to be levied on income from net assets, based on the assumption that a taxable rate of return of 4 percent is made on net assets, irrespective of the actual returns. Thus, under the benchmark rule a 1.2 percent tax should be levied on the accumulated pension savings, irrespective of the actual returns. Additional returns above 4 percent are not taxed.

Figure 1 shows the estimates of the fiscal subsidy for the period 2001-2003 under the new tax regime. The (one-time) effect of lower rates under the Income Tax 2001 diminished the fiscal subsidy on pension savings, but this is counterbalanced by the effect of the sharp increase of the contribution input for pensions in recent years. ${ }^{13}$ In the year 2003, the fiscal subsidy on pension savings under the current Dutch tax rule amounts to 7.0 billion euros ( 1.49 percent GDP). At an annual investment return rate of 5 percent, the subsidy declines to 6.8 billion euros ( 1.45 percent of GDP). Note that due to the tax reform annual rates of return on net assets above 4 percent are not taxed if the benchmark is applied; this explains the remarkable drop of the fiscal subsidy in the year 2001, in case a rate of return of 5 percent is simulated. See Figure 1.

Figure 1 Fiscal subsidy associated with Dutch tax rule as percentage of GDP, 1990-2003

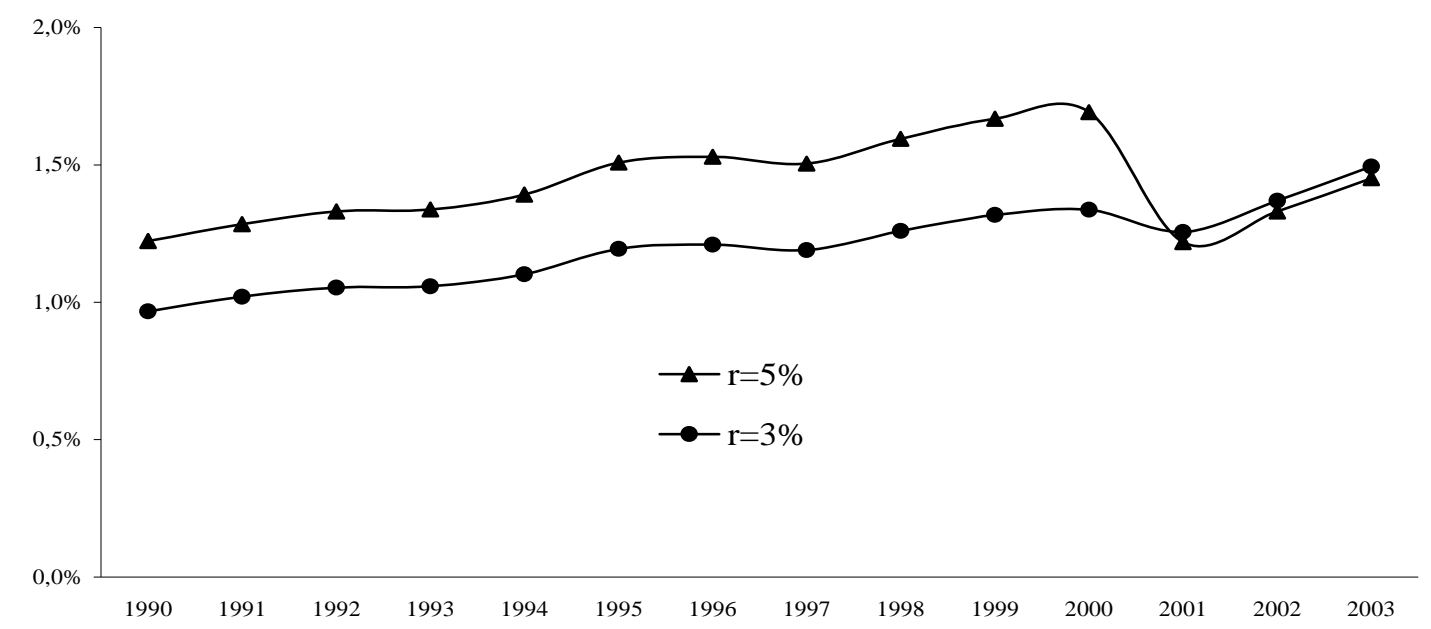

Source: own calculations (build-up period 15 years)

The no-fiscal subsidy case

We have calculated the tax rate on pension benefits under the Dutch tax rule $\left(\mathrm{T}_{\mathrm{b}}{ }^{*}\right)$ that would generate exactly the same amount of tax revenue as under the benchmark rule. When this tax rate would be applied, the fiscal subsidy on pension saving would disappear. Table 3 shows the simulation results both before and after the tax reform 2001.

The equivalent pension benefit tax rate is significantly higher than the actual rate (see equation 9; $\mathrm{T}_{\mathrm{b}}=25.5$ percent). The new Income Tax Act 2001 reduced the fiscal subsidy on pension savings, and has therefore also reduced the equivalent tax rate on pension benefits. In our simulations we find a drop in the equivalent tax rate on pension benefits varying from 4 to 17 percentage points, mainly depending on the investment yield used.

13 The pension investment rose from 3.7 percent of GDP in 2000 to an estimated 4.7 percent in 2003. 
Table 3 Equivalent tax rate on pension benefits

\begin{tabular}{|c|c|c|c|c|c|c|c|c|}
\hline & \multicolumn{4}{|c|}{$\begin{array}{l}\text { Rate of return } 5 \% \\
\text { (discount rate } 5 \% \text { ) }\end{array}$} & \multicolumn{4}{|c|}{$\begin{array}{l}\text { Rate of return } 3 \% \\
\text { (discount rate } 3 \% \text { ) }\end{array}$} \\
\hline & \multicolumn{2}{|c|}{$\begin{array}{c}\text { benchmark } \\
\text { tax rate } \\
\text { TTE }\end{array}$} & \multirow{2}{*}{$\begin{array}{c}\text { actual } \\
\text { tax rate } \\
\text { EET } \\
T_{b}\end{array}$} & \multirow{2}{*}{$\begin{array}{c}\text { equivalent } \\
\text { tax rate } \\
\text { EET } \\
\mathrm{T}_{\mathrm{b}}^{*} \\
\end{array}$} & \multicolumn{2}{|c|}{$\begin{array}{l}\text { benchmark } \\
\text { tax rate } \\
\text { TTE }\end{array}$} & \multirow{2}{*}{$\begin{array}{c}\text { actual } \\
\text { tax rate } \\
\text { EET } \\
\mathrm{T}_{\mathrm{b}}\end{array}$} & \multirow{2}{*}{$\begin{array}{c}\text { equivalent } \\
\text { tax rate } \\
\text { EET } \\
\mathrm{T}_{\mathrm{b}}{ }^{*}\end{array}$} \\
\hline & $\mathrm{T}_{\mathrm{c}}$ & $T_{g}$ & & & $T_{c}$ & $T_{g}$ & & \\
\hline panel (a): year 2000 & & & & & & & & \\
\hline Duration 20 years: tax rates & 44.0 & 44.0 & 25.5 & 78.5 & 44.0 & 44.0 & 25.5 & 66.7 \\
\hline Duration 15 years: tax rates & 44.0 & 44.0 & 25.5 & 71.2 & 44.0 & 44.0 & 25.5 & 61.6 \\
\hline Duration 10 years: tax rates & 44.0 & 44.0 & 25.5 & 63.1 & 44.0 & 44.0 & 25.5 & 56.1 \\
\hline panel (b): year 2001 & & & & & & & & \\
\hline Duration 20 years: tax rates & 41.1 & 30.0 & 25.5 & 61.1 & 41.1 & 30.0 & 25.5 & 62.6 \\
\hline Duration 15 years: tax rates & 41.1 & 30.0 & 25.5 & 56.7 & 41.1 & 30.0 & 25.5 & 57.5 \\
\hline Duration 10 years: tax rates & 41.1 & 30.0 & 25.5 & 51.9 & 41.1 & 30.0 & 25.5 & 52.3 \\
\hline
\end{tabular}

Source: own calculations

\section{Conclusion}

Several OECD countries use tax incentives to encourage private pension savings. These incentives may imply lower tax revenue for the Treasury. This paper investigates the ex ante revenue effects of a cash-flow tax regime for pension savings by full present-value calculations. We used a specified form of a comprehensive income tax system (TTE) as a benchmark. Compared to the comprehensive income tax, the cash-flow tax regime implies lower tax revenue, because tax payments are deferred and returns on accumulated funds are exempted, and because withdrawals are generally subject to lower marginal tax rates than pension contributions. With our model the ex ante revenue effect of the current tax treatment of pension saving in countries can be quantified.

We performed an empirical analysis for the Netherlands as a typical example of a country with significant tax-favored private retirement saving schemes. Our simulations, using Income Panel Data, show that the Dutch tax rule - i.e. taxation on a cash-flow basis - means on balance lower revenue for the Treasury, compared to a specific form of a comprehensive income tax. At a real rate of return on the pension capital of 3 percent and a build-up period of 15 years, the fiscal subsidy in terms of net present value comes to 1.3 percent of the GDP for the year 2000. At a rate of return of 5 percent, the fiscal subsidy on pension saving rises to 1.7 percent of GDP.

The new Income Tax Act 2001 reduced the amount of the fiscal subsidy on pension saving due to the lower relevant tax rates, but the amount of contributions has risen sharply since the year 2000. For the year 2003, we estimate a fiscal subsidy of 1.4 to 1.5 percent of GDP. To present this result in another way: when the current tax rule is maintained, the tax rates on pension benefits should roughly be doubled to fade away the current fiscal subsidy on pension savings in the Netherlands.

The 'loss' of tax revenue due to the favorable tax treatment of pension plans in the Netherlands will probably increase in the near future, because of increasing pension contributions. The tax subsidy on pensions is one of the largest 'tax expenditures' which therefore should be justified. This does not necessarily imply that this tax expenditure should be abolished. Our model and material presented are tentative and do not give any answer on the question whether society would be better off in case alternative tax codes on pension saving would be applied. This would require both a comprehensive economic analysis as social efficiency considerations which are beyond the scope of this paper. 


\section{References}

Antolín, P., Serres, A. de \& Maisonneuve, C. de la (2004). Long-term budgetary implications of taxfavoured retirement saving plans. OECD Economic Studies, No. 39, 2004/2, 25-72.

Booth, P. \& Cooper, D. (2002). The tax treatment of UK defined contributions pension schemes. Fiscal Studies, 23(1), March, 77-104.

Bovenberg, A.L. (2003). Financing retirement in the European Union. International Tax and Public Finance, 10(6), November, 713-734.

Butare, T. (1998). Social needs and the roles of governments and markets: The case of retirement pensions. International Social Security Review, 51(3), July-September, 37-62.

Caminada, K. \& Goudswaard, K.P. (1996). Progression and revenue effects of income tax reform. International Tax and Public Finance, 3(1), January, 57-66.

Caminada, K. \& Goudswaard, K.P. (2004). The fiscal subsidy on pension savings in the Netherlands. Tax Notes International, 33(13), 29 March 2004, 1231-1240.

Economic Policy Committee (2006). The impact of ageing on public expenditure: Projections for the EU25 member states on pensions, health care, long-term care, education and unemployment transfers (2004-2050). European Economy Special Report 1, Brussels: European Commission

European Commission (2006). Adequate and sustainable pensions. Synthesis report 2006. Brussels: European Commission.

Gruber, J. \& Wise D.A. (Ed.) (1999). Social security and retirement around the world. Chicago: The University of Chicago Press.

OECD (1994). Taxation and household saving. Paris: OECD.

OECD (2001). Tax and the economy: a comparative assessment of OECD countries. OECD Tax Policy Studies, No.6. Paris: OECD.

Sinn, H.W. (2005). Europe's demographic deficit. A plea for a child pension system. De Economist, $153(1), 1-45$.

Statistics Netherlands (2006). Data on personal income distribution 1990-2000 (CBS Income Panel Research) to be consulted on the website of Statistics Netherlands (www.cbs.nl) via Statline, the electronic database, Voorburg / Heerlen, Netherlands.

Van Ewijk, C., Draper, N., Rele, H. ter \& Westerhout, E. (2006), Ageing and the sustainability of Dutch public finances. The Hague: Sdu Publishers.

Wise, D.A. (2005). Facing the age wave and economic policy: Fixing public pension systems with healthcare in the wings. Fiscal Studies, 26(1), March, 5-34.

Yoo, K-Y. \& Serres, A. de (2004). Tax treatment of private pension savings in OECD countries. OECD Economic Studies, no.39. 2004/2, 73-110. 